\title{
En kvinne i 70-årene med langvarige gangvansker
}

\author{
Problemer med gangen er en vanlig årsak til henvisning til nevrolog. \\ Vi presenterer en pasient med langsomt progredierende gangvansker \\ og hvitsubstansforandringer på MR-undersøkelse.
}

Pasienten ble henvist til nevrologisk avdeling første gang for omtrent 20 år siden. Hun var da i begynnelsen av 50-årene og hadde om lag ett års sykehistorie med progredierende gangvansker bak seg.

Ved første konsultasjon anga hun at hun hadde hatt styringsvansker i høyre underekstremitet $i$ om lag ett år og økende tendens til å snuble, med forverring de siste seks månedene. Videre beskrev hun manglende evne til å ekstendere tærne og fotbladet uten ledsagende smerter. Pasienten var for øvrig stort sett frisk og brukte ingen faste medikamenter. Hun røykte om lag ti sigaretter daglig og jobbet i full stilling. Hun hadde ingen kjent familiær opphopning av nevrologisk sykdom.

Gangvansker er en vanlig årsak til henvisning til nevrologisk poliklinikk. Ved første vurdering er det viktig å ta stilling til om de kan skyldes nevrologisk sykdom og om det i så fall er snakk om skade i det perifere eller det sentrale nervesystemet.

Den kliniske undersøkelsen vil avgjøre videre utredning. De vanligste årsakene til gangvansker er (i tilfeldig rekkefølge) cerebrovaskulær sykdom, nevrodegenerativ sykdom, inflammatorisk sykdom, degenerative prosesser i columna og polynevropatier.

Ved undersøkelsen fant man lett spastisitet $i$ høyre underekstremitet. Videre hadde pasienten en lettgradig parese for fleksjon og ekstensjon av tærne samt for fleksjon av kneet i høyre underekstremitet. Utover dette var det normale kraftprestasjoner, normalt tempo og normal finmotorikk i ekstremitetene. Ved sensibilitetsundersøkelse var det redusert vibrasjonssans distalt for ankelleddet bilateralt, men bevart leddsans. Det var $ø k t$ refleksutslag symmetrisk i overekstremitetene $(+++)$ og høyredominert hyperrefleksi $i$ underekstremitetene, med subclonus i høyre ankel. Plantarrefleksen var indifferent på høyre side og nedadvent på venstre. Ved undersøkelse av gange over korte avstander var det ikke bemerket spastisk gange, og den ble vurdert som normal. Øvrig nevrologisk undersøkelse var normal.

CT caput uten kontrast viste normale funn, men lett økt subaraknoidalrom. Elek- troencefalogram (EEG) var normalt. Elektromyografi og måling av nerveledningshastigheter (EMG/NCV) var også normale. Intrakranial doppler og doppler halskar var upåfallende. MR caput og medulla spinalis viste langstrakte symmetriske høysignalforandringer av ukjent natur i pons og medulla oblongata på T2-vektede bilder, mest uttalt på venstre side, i tillegg til lett atrofi av medulla oblongata. Lesjonene affiserte blant annet pyramidebanene og kunne samsvare med pasientens sentralnervøse utfall.

Pasienten hadde altså sent debuterende (etter 50 års alder), langsomt progredierende motoriske symptomer, med asymmetriske kliniske funn fra øvre motornevron, mest uttalt i høyre underekstremitet. Det var ingen tegn til affeksjon av nedre motornevron, verken klinisk eller elektrofysiologisk (elektromyografi og nevrografi, EMG/NCV).

I første omgang diskuterte man hvorvidt symptomene kunne være betinget $i$ et kortikalt infarkt, eventuelt $\mathrm{i}$ en lavgradig tumor som ikke ble observert på CT cerebri. Et kortikalt infarkt kan forklare sentralnervøse utfall, men ikke en gradvis progrediering av symptomene. Pasienten røykte, men hadde ellers ingen kjente risikofaktorer for cerebrovaskulær lidelse.

Dopplerundersøkelsen var normal. Mistanke om tumor og infarkt ble avkreftet på MR-undersøkelsen. Imidlertid viste MR cerebri og medulla spinalis høysignalforandringer i pons og medulla oblongata samt lett atrofi av medulla oblongata. Demyeliniserende inflammasjon av type multippel sklerose var lite sannsynlig ut fra MR-funnene på grunn av symmetriske langstrakte forandringer i hjernestammen og lillehjernen. Multippel sklerose vil sjelden gi symmetriske forandringer som strekker seg spesifikt langs bestemte nevroanatomiske baner.

Høysignalforandringer på T2-vektet MR og medullær atrofi kan forekomme ved hereditær spastisk paraplegi (HSP), en gruppe arvelige sykdommer som karakteriseres av gradvis degenerasjon av pyramidebanen $(1,2)$. Andre tilstander som kan gi liknende MR-forandringer er leukodystrofier og andre leukoencefalopatier, det vil si sykdommer som affiserer hvit substans (3).

\author{
Irene H. Flønes \\ Kristoffer Haugarvoll \\ Christina Sundal \\ Charalampos Tzoulis \\ charalampos.tzoulis@helse-bergen.no \\ Nevrologisk avdeling \\ Haukeland universitetssykehus
}

ㄴ.

Engelsk oversettelse på www.tidsskriftet.no 


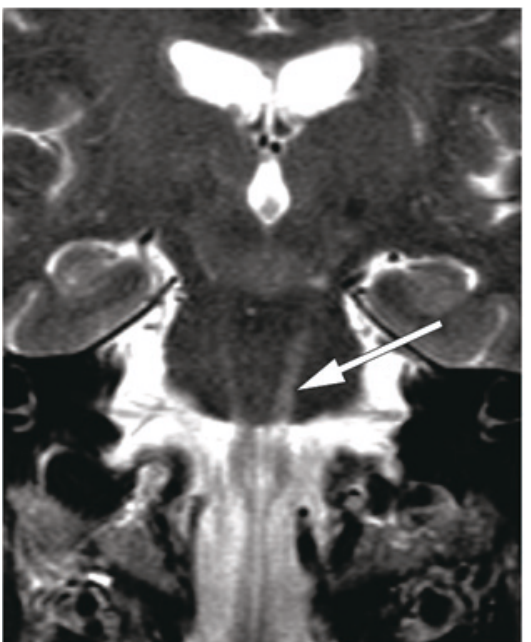

a

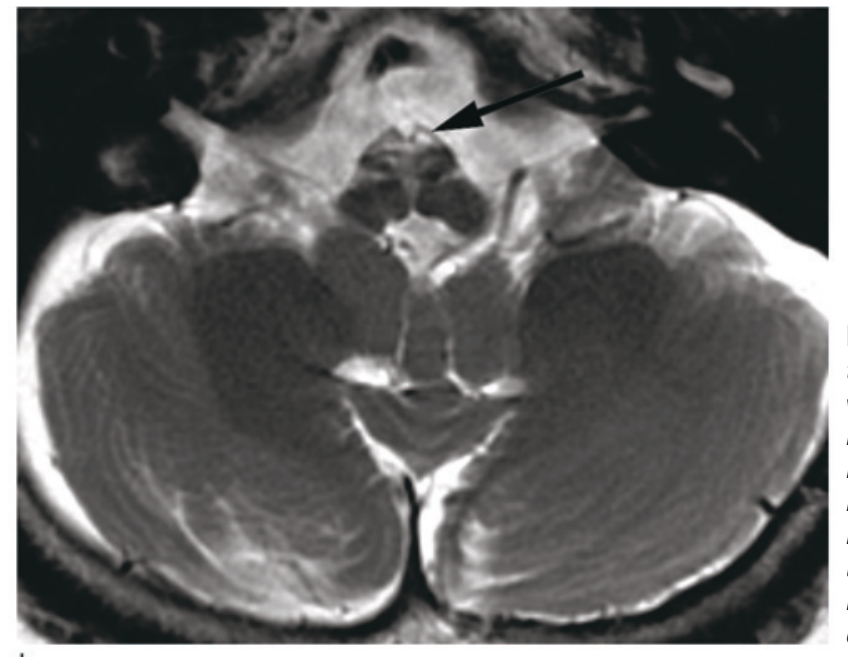

b
Figur 1 MR-undersøkelse av pasientens hjerne, tatt ved 70 års alder. T2vektede bilder. Forandringene er asymmetriske og mest uttalt på venstre side, hvilket korrelerer med pasientens høyredominerte kliniske utfall. a) Koronalt plan viser høysignalforandringer langs pyramidebanene i pons (hvit pill. b) Aksialt plan viser høysignalforandringer i medulla oblongata (svart pil)
I om lag to år ble pasienten fulgt poliklinisk med klinisk undersøkelse. Det var ingen sikker progrediering, men så utviklet hun symptomer fra høyre arm i form av økt klossethet. Ved klinisk undersøkelse var det økt muskeltonus i høyre overekstremitet samt økende kraftsvikt i høyre underekstremitet og svekket hælgang på høyre side.

Pasienten ble innlagt for ny utredning. Visuelt fremkalt respons (VER) og somatosensorisk fremkalt respons (SER) var normale. Auditivt fremkalt respons (AER) viste asymmetri, med avflatet kurve på høyre side. Gjentatt EMG/NCV-undersøkelse og EEG-undersøkelse var normale. Spinalvæskeundersøkelsen var normal, med protein 0,30 (0,15-0,50), Leukocytter 2-1 · 10\% $/ \mathrm{L}$ $1<3 \cdot 10^{9} / /$ og negativ IgM/IgG-borreliaantistoff. Blodprøver, inklusive serologisk prøve for Borrelia, og bred immunologisk screening var normale. MR-undersøkelsen var uendret fra tidligere. Man konkluderte ved utreise at det muligens dreide seg om en øvre motornevronsykdom.

Pasienten hadde sikker progrediering av symptomer. Det var økende svekkelse i høyre underekstremitet, dessuten nyoppstått funksjonssvikt med økt tonus i høyre arm. Utredningen var normal, med unntak av MR-undersøkelsen, som viste uendrede forhold, og AER-undersøkelsen, som viste en avflatet kurve med affeksjon av høyre side.

Dette tolkes som en affeksjon av hjernestammen som gir forsinket auditivt fremkalt respons. Liknende funn er beskrevet hos pasienter med leukodystrofi (4). Pasienten hadde symptomer fra øvre motornevron. Man konkluderte med at hun muligens hadde en form for motornevronsykdom med langsom progrediering.

De følgende årene utviklet pasienten gradvis økende høyresidig spastisk parese, uten sensoriske eller autonome symptomer. Etter om lag ti år med oppfølging ble muligheten for en autosomalt recessiv form for hereditær spastisk paraplegi diskutert, og hun fikk diagnosen sannsynlig hereditær spastisk paraplegi. Fem år senere ble hun reinnlagt ved nevrologisk avdeling for ny vurdering, grunnet atypisk utvikling.

Ny utredning med blodprøver var negativ på nevronantistoffer og encefalittantistoffer, med tanke på paraneoplasi og en rekke andre nevroimmunologiske tilstander, inklusive anti-GAD, med tanke på autoimmunt stivhetssyndrom (stiff person syndrome). Hun hadde normal konsentrasjon av ultralange fettsyrer, med tanke på adrenoleukodystrofi, av fytansyre, med tanke på Refsums sykdom, og av pristansyre, med tanke på alfametylacyl-CoA-racemasemutasjoner, som gir en tilstand med hjernestammelesjoner som likner Refsums sykdom (5).

Det ble ikke påvist mutasjoner i DARS2, genet som gir en form for mitokondriell leukoencefalopati, eller frataxin, med tanke på sent debuterende Friedreichs ataksi. Videre ble hun testet for mutasjoner i noen av de vanligste HSP-assosierte genene (SPG4) $3 A / 7 / 31$, med normale funn. EEG- og EMGundersøkelsene var normale, som tidligere.

De vanligste symptomene ved hereditær spastisk paraplegi er gangforstyrrelser grunnet spastisitet og kraftsvikt sammen med kortikospinale symptomer, eksempelvis hyperrefleksi og invertert plantarrefleks. Spastisiteten vil som regel være symmetrisk. Blæredysfunksjon er relativt vanlig. Sensoriske utfall er sjeldne, men man vil kunne se opphør av vibrasjonssans grunnet affeksjon av bakstrengsbanene (2).

Pasienten fikk diagnosen sannsynlig autosomalt recessiv hereditær spastisk paraplegi på bakgrunn av økende spastisk parese av høyre underekstremitet og opphør av vib- rasjonssans i underekstremitetene. Imidlertid hadde hun ingen spastisk blæreparese, utfallene var unilaterale og hun testet negativt for de vanligste mutasjoner ved hereditær spastisk paraplegi, hvilket talte imot diagnosen.

På bakgrunn av atypiske kliniske funn valgte man à gjennomføre MR cerebri i 3-teslaskanner. Pasienten var da 70 år gammel. Undersøkelsen viste generelt vide sulci frontalt og parietalt og markert fissura interhemispherica, forenlig med cerebral atrofi.

Det ble beskrevet symmetrisk signalavvik og atrofi ventralt i medulla oblongata, svarende til pyramidebanen. Signalavviket fortsatte sidelikt oppover i pons, men mesencephalon var spart. Forandringene strakte seg nedover i medulla spinalis til midttorakalt nivå. I tillegg var det symmetriske høysignalforandringer i nucleus dentatus cerebelli på T2-vektede bilder (fig 1).

Etter revurdering av kliniske funn, bildediagnostikk og tidligere utredning ble det konkludert med at tilstanden kunne minne om sent debuterende Alexanders sykdom.

Dette er en arvelig lidelse som skyldes mutasjoner i GFAP-genet (som koder for «glial fibrillary acidic protein»). Den kjennetegnes av progredierende hvitsubstansforandringer samt bred og varierende nevrologisk affeksjon.

På bakgrunn av dette ble det utført en ny spinalpunksjon for måling av spinal GFAP. Undersøkelsen viste klart forhøyede nivåer, med spinal GFAP på $5870 \mathrm{ng} / \mathrm{l}$ (< $1250 \mathrm{ng} / \mathrm{ll}$. Det ble dernest utført en genetisk analyse for vurdering av mutasjoner i GFAP-genet. Svar på den genetiske analysen viste en heterozygot endring, c.196 C > G, hvilket medfører substitusjon av aminosyren arginin i posisjon 66 på proteinet av glycin (p.R66G). 
Varianten er ikke tidligere beskrevet, men vurderes å være sykdomsgivende ut fra predikert effekt på proteinstruktur og -funksjon. Det ble derfor konkludert med at pasienten hadde sent debuterende Alexanders sykdom.

\section{Diskusjon}

Alexanders sykdom er en av mange leukodystrofier, det vil si tilstander som affiserer hvit substans i sentralnervesystemet. Leukodystrofiene kjennetegnes generelt av defekter i syntese og vedlikehold av myelin, den modifiserte plasmamembranen fra oligodendrocytter (i sentralnervesystemet) som beskytter og isolerer nervefibrene. Alexanders sykdom debuterer vanligvis i ung alder, men juvenile og voksne varianter forekommer $(6,7)$. Prevalensen er ukjent, men under 550 tilfeller av sykdommen er rapportert (7).

Sykdommen skyldes en mutasjon i genet som koder for GFAP, et intermediat filamentprotein som finnes i modne astrocytter og som raskt syntetiseres ved skader og reaktiv astrogliose. Mutasjonene forstyrrer dimeriseringen av GFAP-proteinet, hvilket fører til kollaps av cytoskjelettet og en unormal proteinaggregering $(8,9)$.

Alexanders sykdom kan være familiær eller sporadisk. Den familiære formen er autosomalt dominant, det vil si at mutasjonen arves fra en av foreldrene og det er $50 \%$ risiko for sykdom hos hvert barn. Den sporadiske formen skyldes en nyoppstått (de novo) mutasjon i genet, og det er ingen andre tilfeller i familien. Juvenile og infantile former er antatt stort sett å være spontane mutasjoner, da pasientene ofte ikke vil være i stand til å få barn. Den voksne formen kan være et resultat av en sporadisk mutasjon, men familiære former er beskrevet $(1,10,11)$.

Vår pasient hadde verken foreldre, barn eller andre slektninger med sykdommen, og det er derfor rimelig å anta at hun har den sporadiske formen på grunn av en de novomutasjon. For å påvise dette med sikkerhet bør man vise at mutasjonen ikke finnes hos pasientens foreldre, men $\mathrm{i}$ vårt tilfelle var dette dessverre ikke mulig, da disse ikke lenger var i live.

Pasienter med sent debuterende Alexanders sykdom har et variert klinisk bilde, som kan inkludere hjernestammedysfunksjon (dysfagi, dysfoni, dysartri), pyramidebanetegn (spastisitet, hyperrefleksi, invertert plantarrefleks), cerebellære symptomer (ataksi, nystagmus, dysmetri), dysautonomi, søvnapné, gangforstyrrelser, hemiparese/hemiplegi, eventuelt kvadriparese/kvadriplegi, krampeanfall og/eller diplopi (7).

MR-karakteristika varierer med debutalder. Typisk for voksne er markert atrofi av infratentorielle strukturer, vanligst medulla oblongata, men også i resterende deler av hjernestammen, cerebellum og cervikale deler av medulla spinalis $(12,13)$. Det er beskrevet funn på MR før kliniske symptomer (14). Alexanders sykdom diagnostiseres klinisk og radiologisk. Genetisk testing kan bekrefte diagnosen. Det finnes ingen aktiv behandling, men symptomatisk behandling er viktig (7).

Vår pasient har vært fulgt ved nevrologisk avdeling i 20 år og har i løpet av denne tiden kun hatt langsomt progredierende motoriske symptomer $\mathrm{i}$ form av spastisk hemiparese. Hennes kliniske symptomer var uspesifikke, og det var en lang liste av differensialdiagnoser: neoplasi, inflammasjon/infeksjon, nevrodegenerative tilstander, som motornevronsykdom, og en stor og heterogen gruppe arvelige sykdommer, inklusive hereditær spastisk paraplegi og leukodystrofier. Mest avgjørende for diagnostikken var MR-funnene. Bilaterale langstrakte lesjoner som selektivt affiserer spesifikke baner i hjernestammen/ medulla spinalis tyder sterkt på hereditær, metabolsk eller degenerativ tilstand.

Arvelige leukodystrofier debuterer vanligvis i barndommen og blir som regel diagnostisert av nevropediater. Det finnes imidlertid flere varianter som opptrer i løpet av voksenlivet. Pasientene kan være vanskelig å diagnostisere, da de ofte avviker fra «lærebokbeskrivelsene» og har atypiske symptomer og funn. Andre eksempler er voksendebuterende varianter av metakromatisk leukodystrofi, Krabbes sykdom og adrenoleukodystrofi. Det er viktig å inkludere disse differensialdiagnosene også hos voksne pasienter med hvitsubstanssykdom av ukjent årsak, hvor vanligere årsaker som multippel sklerose eller kronisk cerebral iskemi er blitt utelukket.

Pasienten har gitt samtykke til at artikkelen blir publisert.

\section{Irene H. Flønes (f. 1986)}

er lege i spesialisering.

Forfatter har fylt ut ICMJE-skjemaet og oppgir ingen interessekonflikter.

\section{Kristoffer Haugarvoll (f. 1976)}

er ph.d., spesialist i nevrologi og overlege. Forfatter har fylt ut ICMJE-skjemaet og oppgir ingen interessekonflikter.

\section{Christina Sundal (f. 1976)}

er ph.d. og spesialist i nevrologi.

Forfatter har fylt ut ICMJE-skjemaet og oppgir ingen interessekonflikter.

\section{Charalampos Tzoulis (f. 1979)}

er ph.d., spesialist i nevrologi og overlege. Forfatter har fylt ut ICMJE-skjemaet og oppgir ingen interessekonflikter.
Litteratur

1. Hourani R, El-Haji T, Barada WH et al. MR imaging findings in autosomal recessive hereditary spastic paraplegia. AJNR Am J Neuroradiol 2009; 30: $936-40$.

2. Salinas S, Proukakis C, Crosby A et al. Hereditary spastic paraplegia: clinical features and pathogenetic mechanisms. Lancet Neurol 2008; 7 : 1127-38

3. Romano S, Salvetti M, Ceccherini I et al. Brainstem signs with progressing atrophy of medulla oblongata and upper cervical spinal cord L Lancet Neurol 2007; 6: 562-70.

4. Ichiyama T, Hayashi T, Ukita T. Two possible cases of Alexander disease. Multimodal evoked potentials and MRI. Brain Dev 1993; 15: 153-6.

5. Haugarvoll K, Johansson S, Tzoulis $C$ et al. MRI characterisation of adult onset alpha-methylacylcoA racemase deficiency diagnosed by exome sequencing. Orphanet J Rare Dis 2013; 8: 1

6. Barkovich AJ, Messing A. Alexander disease: not just a leukodystrophy anymore. Neurology 2006 66: $468-9$.

7. Gorospe JR. Alexander disease. I: Pagon RA, red Seattle (WA): GeneReviews(R), 1993. www.ncbi.nlm nih gov/books/NBK1172/ (19.6.2015)

8. Eng LF, Ghirnikar RS, Lee YL. Glial fibrillary acidic protein: GFAP-thirty-one years (1969-2000). Neurochem Res 2000; 25: 1439-51.

9. Brenner $M$, Johnson AB, Boespflug-Tanguy 0 et al. Mutations in GFAP, encoding glial fibrillary acidic protein, are associated with Alexander disease. Nat Genet 2001; 27: 117-20.

10. Stumpf E, Masson H, Duquette A et al. Adult Alexander disease with autosomal dominant transmission: a distinct entity caused by mutation in the glial fibrillary acid protein gene. Arch Neurol 2003, 60: 1307-12.

11. Prust M, Wang J, Morizono $\mathrm{H}$ et al. GFAP mutations, age at onset, and clinical subtypes in Alexander disease. Neurology 2011; 77: 1287-94.

12. Yoshida T, Nakagawa M. Clinical aspects and pathology of Alexander disease, and morphological and functional alteration of astrocytes induced by GFAP mutation. Neuropathology 2012; 32 . 440-6.

13. Farina $L$, Pareyson D, Minati $L$ et al. Can MR imaging diagnose adult-onset Alexander disease? AJNR Am J Neuroradiol 2008; 29: 1190-6.

14. Okamoto Y, Mitsuyama H, Jonosono M et al. Auto somal dominant palatal myoclonus and spinal cord atrophy. J Neurol Sci 2002; 195: 71-6.

Mottatt 27.1. 2015, første revisjon innsendt 14.5 2015, godkjent 19.6. 2015. Redaktør: Lise Mørkved Helsingen. 